\title{
Effects of the Oil Shocks, Interest Rate, and Current Account Balance on the Sovereign Debt of CEMAC Member Countries
}

\author{
Michel Okiemy, Guénolé Mbongo Koumou \\ Laboratoire de Recherches et d'Etudes Economiques et Sociales (LARES), Faculté des Sciences Economiques, \\ Université Marien Ngouabi, Brazzaville, Congo \\ Email: michel.okiemy@umng.cg, gmbongo@hotmail.fr
}

How to cite this paper: Okiemy, M., \& Mbongo, K. G. (2021). Effects of the Oil Shocks, Interest Rate, and Current Account Balance on the Sovereign Debt of CEMAC Member Countries. Modern Economy, 12, 194-214.

https://doi.org/10.4236/me.2021.121010

Received: December 5, 2020

Accepted: January 26, 2021

Published: January 29, 2021

Copyright $\odot 2021$ by author(s) and Scientific Research Publishing Inc. This work is licensed under the Creative Commons Attribution International License (CC BY 4.0).

http://creativecommons.org/licenses/by/4.0/

\begin{abstract}
The objective of this paper is to analyze the effects of oil shocks, interest rates and balance of payment on the sovereign debt of member countries of the Central African Economic and Monetary Community (CEMAC) from 1998 to 2018 using the nonlinear autoregressive distributed lag (NARDL) method. The obtained results demonstrate short- and long-term asymmetric relationships among oil shocks, interest rate, and balances of payment on the sovereign debts of these countries. A positive long-term shock increases sovereign debt, while debt services deteriorate during negative short-term shocks, which demonstrates the procyclical behavior of the debt of these countries. These results enable us to formulate implications for economic policies to improve budget management and diversify the economy.
\end{abstract}

\section{Keywords}

Asymmetries, Sovereign Debt, Oil Shocks, Interest Rate,

Balance of Payment, NARDL

\section{Introduction}

The global capital market has experienced sovereign defaults ${ }^{1}$, and from 1824 to 1999, emerging countries have experienced on average three defaults or re-structuring crises every 100 years (Reinhart et al., 2003). Among the episodes of defaults and restructuring, the economics literature considers those of Latin American countries (Brazil, Argentina, Venezuela and Mexico).

${ }^{1}$ Default is the scenario in which the debtor violates the legal terms of the debt contract. The debtor might fail to pay the interest and principal within the specific grace period (Tomz \& Wright, 2013). 
However, these episodes have affected not only Latin American countries but also European countries (Spain, Greece, Germany, and France) since the 16th century (Reinhart et al., 2003). Moreover, during a period of default or restructuring, the debt-to-GDP ratio tends toward $71 \%$ on average. Analyzing these historical facts, Tomz and Wright (2007) argue that defaults often occur in bad times when the level of activity is on average $1.6 \%$ below the trend. Reinhart and Rogoff (2009) argue that defaults often coincide with financial crises and commodity cycles, especially oil shocks.

Defaults are also influenced by the behavior of the interest rate at which economies borrow from the rest of the world and the balance of payments, which are highly countercyclical and positively correlated. Hence, emerging markets increase their borrowing in good times when interest rates are low, in contrast to times of crisis (Aguiar \& Gopinath, 2004). The variables that are discussed above can also justify borrowing and defaults in developing countries (DCs).

Following a positive shock due to a rise in oil prices, there is an improvement in the balance of payments. Consequently, oil-exporting DCs increase both their investments in basic infrastructure (communication networks, energy, water, hospitals, and education), which contribute enormously to the economic growth of the States (Mankiw et al., 1992), and their indebtedness to compensate for the low level of savings. In addition, the rise in oil prices tends to reduce the ratio of debt service to exports (which enables the capture of sovereign debt) as the level of exports improves.

However, following a negative shock, due to the fall in oil prices, there is a deterioration in the balance of payments, and oil-exporting DCs are not only denied access to international credit (Eaton \& Gersovitz, 1981) but also must repay or borrow at very high interest rates. The demand for foreign capital by oil-exporting DCs in times of crisis can be explained by the nonproductivity of the investments that were made during the period of activity.

Thus, all these concerns lead us to analyze the effects of oil shocks, interest rates, and balances of payments on the sovereign debt of Central African Economic and Monetary Community (CEMAC) member countries, the economies of which depend on raw materials, which renders them vulnerable to exogenous shocks, especially those that are due to oil price fluctuations. According to the IMF $(2017)^{2}$, the debt-to-GDP ratio in CEMAC increased from $22 \%$ in 2013 to $50.4 \%$ in 2016 . Congo's debt ratio rose to more than $100 \%$ (114.6\%), while those of Gabon, CAR and Chad rose to 50\% and that of Cameroon rose from $21.5 \%$ in 2014 to $34.4 \%$ in 2019 . The increase in the debt-to-GDP ratio is explained by the weak fiscal balance that is related to the 2014 drop in oil prices, weak growth due to higher interest rates that increase debt service, and other factors that are related to governance.

Due to all these concerns, the risk of default is high for exporting countries ${ }^{2}$ IMF (2017), no $17 / 393$. 
during a negative shock due to falling oil prices because theoretically, when oil prices fall, the interest rate increases, thereby leading to a deterioration of the current account balance. Thus, in this study, we formulate the research question as follows: What are the effects of oil shocks, interest rate, and balance of payments on the sovereign debt of CEMAC member countries? The objective is to analyze the effects of oil shocks, interest rates and balance of payment on sovereign debt.

The remainder of this paper is organized as follows: Section 2 presents a literature review. Section 3 presents a descriptive analysis of the relationship among oil shocks, sovereign debt, interest rates and balance of payments in CEMAC countries. Section 4 describes the methodology, and Section 5 presents the conclusions of this study and discusses implications on economic policies.

\section{Literature Review}

The literature review consists of theoretical and empirical reviews.

\subsection{Theoretical Review}

This review surveys studies on the effects of oil shocks on the economy. We begin with the seminal work of Bruno and Sachs (1985), who analyzed for the first time the effects of the 1970 oil shocks on GDP and inflation in most industrialized countries. We analyze the effects of oil shocks, interest rates and balance of payments on sovereign debt. Bernanke, Gertler and Watson (1997) argue that the observed decreases in income and employment were due to the increase in the interest rate that resulted from the endogenous response of the FED to the high inflation that was generated by the oil shocks. Consequently, the tightening of the interest rate by monetary policy to address the rise in oil prices in the 1980s was one of the causes of the increase in borrowing by developing countries. Indeed, this period also corresponded to a decline in commodity prices on which the economies of exporting countries depended.

Moreover, according to Aguiar and Gopinath (2004), recent sovereign defaults in emerging countries are accompanied by high interest rates and deep recessions. The probability of default and the interest rate depend on the incentive to repay. Default intervenes in equilibrium when market assets are incomplete. The incentive to default and the interest rate are high in recessions, which correspond to periods of falling oil prices.

Under these conditions, a risk-averse borrower finds it more costly to repay noncontingent debt and is more likely to default. Furthermore, Eaton and Gersovitz (1981) argue that reputation deters debtors from defaulting. Indeed, by defaulting, the debtor is immediately and definitively excluded from access to external financing. There is no partial default if the debt service is not ensured in its entirety; hence, the debtor has no interest in repaying part of his debt. From this perspective, Bulow and Rogoff (1989) argue that the incentive constraint that is based on the reputational mechanism cannot be sufficient to ensure that 
debt service is not met. Indeed, the total restriction of access to financing to the defaulter presupposes complete and symmetrical information and perfect coordination of creditors. However, after 1982, the predominance of external bank financing in DCs gave way to the diversification of sources of financing in later periods; thus, credit rationing is no longer credible. In this context, the direct sanction model that is based on the seizure of assets of the defaulter in international transactions comes into play.

In summary, in emerging markets, sovereign defaults are accompanied by the scenario in which temporal movements in the interest rate are dictated by changes in the default rate, and the rigidity of the interest rate hinders the identification of any qualitative correspondence between the positive correlation between interest rates and the current account. An increase in borrowing in good times (countercyclical current account) will lead, all other things being equal, to a movement along the "loan supply curve" and a sharp rise in the interest rate.

In contrast, if a suitable period persists, the expected probability of default is reduced, and such a period is associated with a favorable temporal change in the interest rate (Arellano, 2008). The Keynesian approach $(1924)^{3}$, which is based on the behavior of international financial markets, may provide an alternative. Thus, the incentive condition is no longer a standard condition that is based on the presence of a sanction; it depends on a simple link between inflows and outflows. Consequently, if net flows are positive, for example, due to a positive oil price shock, debt service is guaranteed; otherwise, it is not.

\subsection{Empirical Review}

In the empirical review, it is difficult to establish an econometric model that links oil shocks to sovereign debt through the trade channel. The techniques that are employed include structural VAR to analyze the macroeconomic effects of oil shocks (Blanchard \& Galí, 2008; Kilian, 2008) and the stochastic general dynamic equilibrium model (Eaton \& Gersovitz, 1981). The results demonstrate that most US recessions were preceded by rising oil prices; thus, rising oil prices are regarded as the main cause of recessions (Hamilton, 1996). However, this assertion has recently been questioned by (Hooker, 1996; Herrera \& Pesavento, 2007; Edelstein \& Kilian, 2007).

Indeed, the hypothesis that the effects of oil prices have changed over time is most consistent with other factors (Blanchard \& Galí, 2008). By replicating the work of Kilian (2009), followed by a panel (estimation of the fixed effects of the pooled panel model), Buetzer et al. (2012) show that a rise in the ratio of the oil trade balance to GDP of $1 \%$ leads to a $1.6 \%$ increase in external reserves after a shock that increases the price of oil by $10 \%$.

This shock, which increases external reserves, also increases the capacity of a state's external commitments. In addition, the results that were obtained by $\mathrm{Al}-$

${ }^{3}$ KEYNES J.-M. (1924) "Foreign investment and national advantage", The Nation and the Athenæum, P. 584-587. 
legret et al. (2015), who extended the studies of Kilian (2009) and Buetzer et al. (2012) using a time-varying parameter structural vector autoregression (TVP-VAR) model, show that the exchange rate reacts positively to demand shocks and oil market shocks, in contrast with supply shocks.

For the empirical review on sovereign debt, the estimation techniques are based on the dynamic stochastic general equilibrium and Markov chain models of Eaton and Gersovitz (1981) and Bulow and Rogoff (1988). These models are based on reputation, namely, a defaulter is immediately and definitively excluded from access to external financing in the former, and direct sanction, namely, a defaulter's assets are seized during international transactions in the latter.

The reputation model has disadvantages when it only considers a period for the duration of the bond, since the government can contract short- and long-term debt according to Bulow and Rogoff (1989), and when it retains only one consumer good, since the government can currently diversify its borrowing into several currencies (Tomz \& Wright, 2013). They document that $62 \%$ of defaults begin when GDP is below the trend and that this trend corresponds to the rise or fall of oil prices (as in the cases of Ecuador in 2008 and Greece in 2015), according to Aguiar and Amador (2016). The results that were obtained from the estimates also demonstrated that the incentive to default is high when the level of income is low, with a negative correlation between the interest rate and GDP and a negative correlation between the exchange rate and the interest rate leading to a noncyclical trade balance (Arellano, 2008).

These results are similar to those that were obtained by Aguiar and Gopinath (2004). More recently, to measure the macroeconomic effects of oil shocks, many authors have used the nonlinear autoregressive distributed lag (NARDL) method to capture both the short- and long-term asymmetric effects of oil shocks on economic activity. Thus, over a period from 1980 to 2015, Adedeji et al. (2018) identified an asymmetrical relationship between oil shocks and economic growth in Nigeria and Angola. Oil prices have significant impacts with positive and negative effects on the GDP of these two countries.

\section{Descriptive Analysis of the Relationship between Oil Shocks and Sovereign Debt in Cameroon, Congo and Gabon}

This section analyses the statistical relationship among oil earnings shocks, fiscal policy, and human development in Cameroon, Congo, and Gabon from 1998 to 2017. The choices of the three CEMAC member countries and the study period are dictated by data availability. In the CEMAC zone, the Central African Republic (CAR) is an oil-producing country, while Chad and Equatorial Guinea have only been oil-producing countries since the early 2000s.

In this study, the value of monetary policy is decisive insofar as CEMAC countries are in a fixed exchange rate regime. Under these conditions, the hy- 
pothesis of a short-term interest rate (INT) is used since there may be imperfections in the substitution between domestic and foreign assets (Lahiri \& Végh, 2003). We use the ratio of debt service to exports to capture the effects on sovereign debt (DS). This ratio is important at the point where assistance under the heavily indebted poor countries (HIPC) initiative is defined on the basis of a target for this ratio of public debt to exports. The debt-to-export ratio indicates whether a country can expect sufficient foreign exchange earnings to cover its future external debt obligations (World Bank, 2013) ${ }^{4}$. The ratio enables us to analyze the effects of oil shocks on sovereign debt (Kaminsky, 2003). The behavior of the current account can be measured by the real effective exchange rate (TEER on 2005 basis), which is available from the United Nations Conference on Trade and Development (UNCTAD) database. It covers both the monetary value between currencies and the relative price of traded goods. Real exchange rate appreciation is the most important signal of a future crisis (Kaminsky, 2003; Goldfajn \& Valdés, 1996; Frankel \& Rose, 1996). The price of oil (PP) is used to capture oil shocks. The evolutions of the variables in the three CEMAC countries for the period of 1998 to 2017 are presented in the following graphs:

The three graphs show that in Cameroon (Graph 1), the rise in oil prices in the third quarter of 1998 initially caused the level of sovereign debt to fall until the early 2000s. Then, it peaked between 2003 and 2007. From the third quarter of 2007, the debt fell again, which coincided with a rise in oil prices. Thus, in Cameroon, the level of debt tends to fall as oil prices increases. In the Congo (Graph 2), the debt increased with the rise in oil prices from the third quarter of 1993 to 2004. However, between the third quarter of 2007 and 2017, the debt fluctuated. In Gabon (Graph 3) shows an alternation between debt and oil price shocks, with a peak in 2007.

In summary, these three graphs show the relationships between oil price shocks and sovereign debt services in Cameroon, Congo, and Gabon.

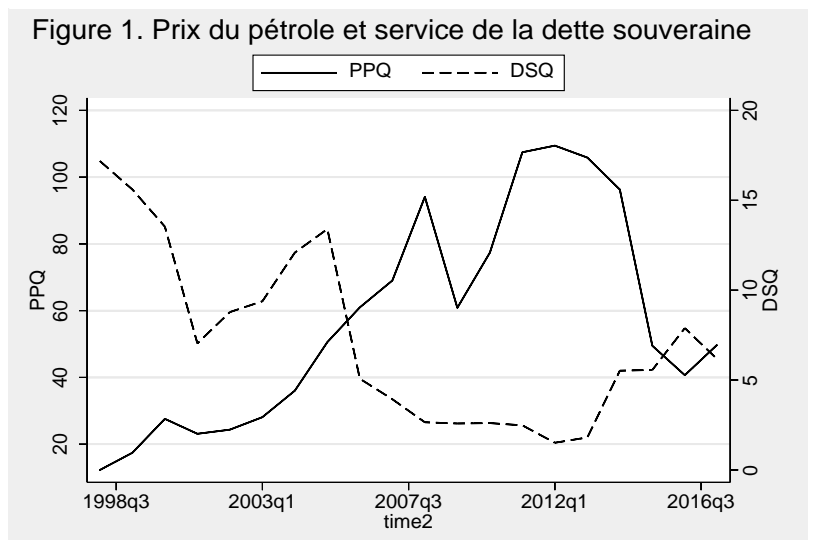

Graph 1. Oil shock and sovereign debt relationship for Cameroon (1998-2017). Sources: authors on the basis of data (WDI and CNUCED, 2020).

${ }^{4}$ World Bank (2013): "International Debt Statistics". 


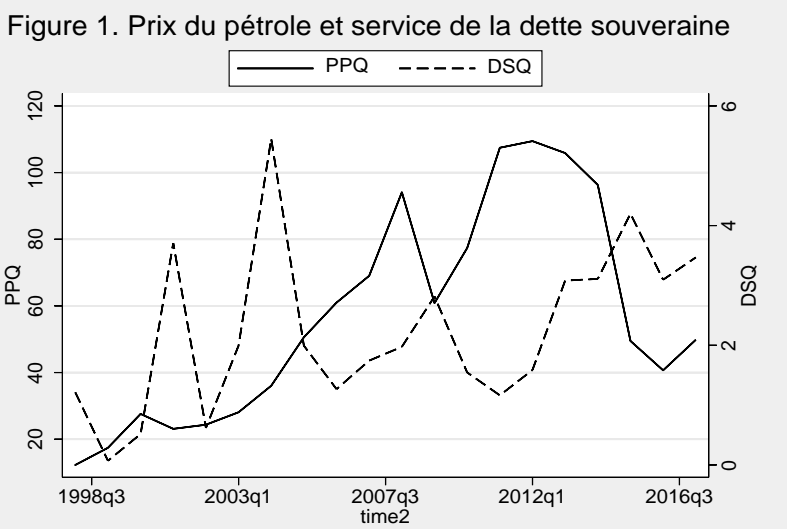

Graph 2. Oil shock and sovereign debt relationship for Congo (1998-2017). Source: authors on the basis of data (WDI and CNUCED, 2020).

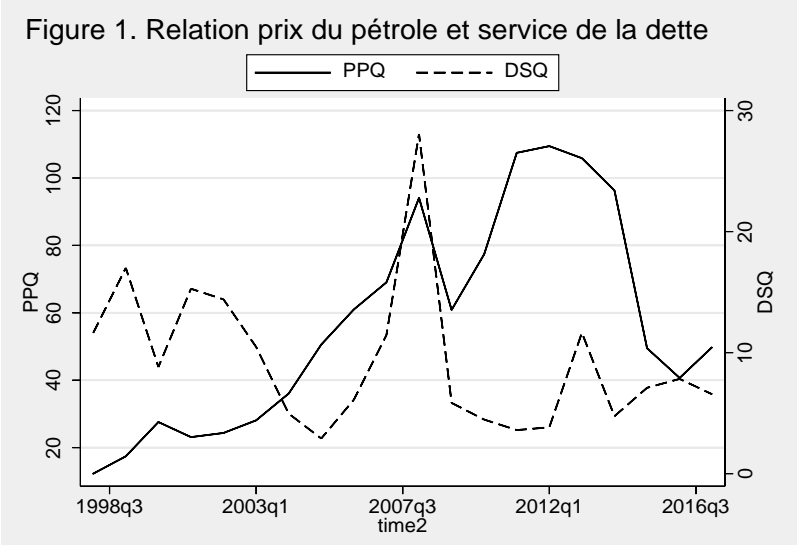

Graph 3. Oil shock and sovereign debt relationship for Gabon (1998-2017). Source: authors on the basis of data (WDI and CNUCED, 2020).

\section{Methodology}

The methodology consists of analyzing the relationship among oil shocks, interest rates, and the current account balance on the sovereign debt of Cameroon, Congo, and Gabon over a period from 1998 to 2017.

\subsection{Model Selection and Specification}

The analysis of the effects of oil shocks, interest rates, and current account balance on sovereign debt is based on the nonlinear ARDL (nonlinear autoregressive distributed lag, NARDL) method, which is an extension of a dynamic model of the linear version of the ARDL model by Shin et al. (2014). They argue that the direction of asymmetry oscillates between the short and long term, with the assumption that positive shocks can have large absolute effects in the short term and negative shocks can have large absolute effects in the long term. In their specification, Shin et al. (2014) extracted the nonlinear asymmetric cointegration model from Pesaran and Shin (1998), Pesaran et al. (2001), and Schorderet 
(2003), which is expressed as follows:

$$
y_{t}=\lambda^{+} \chi_{t}^{+}+\lambda^{-} \chi_{t}^{-}+\mu_{t}
$$

where $\lambda^{+}$and $\lambda^{-}$are parameters that are related to the long- and short-term asymmetries that are associated with positive $\chi_{t}^{+}$or negative $\chi_{t}^{-}$changes and satisfy the partial sum $\chi_{t}=\chi_{0}+\chi_{t}^{+}+\chi_{t}^{-}$, which are defined as follows:

$$
\begin{aligned}
& \chi_{t}^{+}=\sum_{i=1}^{t} \Delta \chi_{i}^{+}=\sum_{i=1}^{t} \max \left(\Delta \chi_{i}, 0\right), \\
& \chi_{t}^{-}=\sum_{i=1}^{t} \Delta \chi_{i}^{-}=\sum_{i=1}^{t} \max \left(\Delta \chi_{i}, 0\right)
\end{aligned}
$$

$\mu_{t}$ represents the error term. Then, the error-correction model can be expressed as follows:

$$
\Delta y_{t}=\rho y_{t-1}+\delta^{+} \chi_{t-1}^{+}+\delta^{-} \chi_{t-1}^{-}+\sum_{i=1}^{p-1} \varphi_{j} \Delta y_{t-j}+\sum_{j=0}^{q}\left(\gamma_{j}^{+} \Delta \chi_{t-j}^{+}+\gamma_{j}^{-} \chi_{t-j}^{-}\right)+\varepsilon_{t}
$$

Thus, we summarize the four-step estimation process in a single step, in which long-term asymmetries are calculated as follows:

$\lambda^{+}=-\frac{\delta^{+}}{\rho}$ and $\lambda^{-}=-\frac{\delta^{-}}{\rho}$ are long-term parameters.

\subsection{Model Specification}

The implementation of the empirical analysis is based on the studies of Abdel-Latif et al. (2018) and Adedeji et al. (2018) on empirical evidence of the asymmetry of oil price shocks in the economies of Nigeria and Angola using NARDL methods. It is expressed as follows:

$$
D S_{t}=f(p p, i n t, t e e r)
$$

The following decomposition is applied:

$$
D S_{t}=f\left(p p^{+}, p p^{-}, \text {int }^{+}, \text {int }^{-}, \text {teer }^{+}, \text {teer }^{-}\right)
$$

where $\mathrm{pp}^{+}, \mathrm{pp}^{-}$, int $^{+}$, int $^{-}$, teer $^{+}$, teer $^{-}$are the positive and negative decompositions of the oil price, the interest rate and the real effective exchange rate, respectively. Thus, in this study, the asymmetric nonlinear model is expressed as follows:

$$
\begin{aligned}
\Delta D S_{t}= & \alpha+\varphi D S_{t-1}+\delta_{1} p p_{t-1}^{+}+\delta_{1} p p_{t-1}^{-}+\delta_{2} \text { int }_{t-1}^{+}+\delta_{2} \text { int }_{t-1}^{-}+\delta_{3} \text { teer }_{t-1}^{+} \\
& +\delta_{3} \text { teer }_{t-1}^{-}+\sum_{j=0}^{q} \delta_{i} D S_{t-1}+\sum_{j=0}^{q} \gamma_{1}^{+} \Delta p p_{t-1}^{+}+\sum_{j=0}^{q} \gamma_{1}^{-} \Delta p p_{t-1}^{-}+\sum_{j=0}^{q} \gamma_{2}^{+} \Delta i n t_{t-1}^{+} \\
& +\sum_{j=0}^{q} \gamma_{2}^{+} \Delta i n t_{t-1}^{-}+\sum_{j=0}^{q} \gamma_{3}^{+} \Delta \text { teer }_{t-1}^{+}+\sum_{j=0}^{q} \gamma_{3}^{+} \Delta \text { teer }_{t-1}^{-}+\varepsilon_{t}
\end{aligned}
$$

\subsection{Using Data and Sources}

In this paper, we consider a sample of three exporters of oil, members of CEMAC. Turning to data and as stressed above, four variables are considered at the quarterly frequency. Data on oil shocks (PP), the interest rate (INT), and so- 
vereign debt are available from World development indicators (WDI) and International Energy Agency (IEA) database; data on the real effective exchange rate (RER) are available on UNCTAD database, over a period from 1998 to 2017. In this study, to obtain a normal series, the statistical data were divided quarterly on interviews9 using the Denton (1971) approach. This technique can preserve the movements in the first series as well as possible (Di Fonzo \& Marini, 2012); this is not the case with other techniques.

\subsection{Presentation of the Results and Interpretations}

The results of the descriptive statistics for the three countries are presented in the three tables. To establish the level of dispersion or to compare distributions with noncomparable measurement scales, we calculate the coefficient of variation, which relates the standard deviation of an estimate to the mean of that estimate. The lower the value of the coefficient of variation, the more accurate the estimate.

The results in the right-hand column show that the ratio of standard deviation (coefficients of variation) to the mean is low relative to the mean for all variables in Cameroon (Table 1), Congo (Table 2) and Gabon (Table 3). This leads to the conclusion that the series is weakly dispersed. Thus, there is some convergence between the economies of these three countries, which have the same monetary policy.

Table 1. Descriptive statistics and results for the Cameroun.

\begin{tabular}{ccccccc}
\hline Variable & Obs. & Mean & Std. Dev. & Min & Max & Std/Mean \\
\hline $\mathrm{dsq}$ & 77 & 7.067015 & 4.509576 & 1.513015 & 17.18302 & 0.63811609 \\
$\mathrm{ppq}$ & 77 & 58.06227 & 30.61019 & 12.28 & 109.45 & 0.52719589 \\
intq & 77 & 4.062074 & 3.269009 & 0.71386 & 11.90528 & 0.80476353 \\
teerq & 77 & 103.4363 & 3.310668 & 96.45475 & 108.4528 & 0.03200683 \\
\hline
\end{tabular}

Sources: authors on the basis of data (WDI and CNUCED, 2020).

Table 2. Descriptive statistics and results for the Congo.

\begin{tabular}{ccccccc}
\hline Variables & Obs. & Mean & Std. Dev. & Min & Max & Std/Mean \\
\hline dsq & 77 & 2.226687 & 1.159754 & 0.0703499 & 5.452688 & 0.52084285 \\
ppq & 77 & 58.06227 & 30.61019 & 12.28 & 109.45 & 0.52719589 \\
intq & 77 & 0.8362348 & 0.5173743 & 0.1912077 & 2.457525 & 0.61869501 \\
teerq & 77 & 100.1868 & 8.365879 & 81.95385 & 115.7053 & 0.03281508 \\
\hline
\end{tabular}

Sources: authors on the basis of data (WDI and CNUCED, 2020).

Table 3. Descriptive statistics and results for the Gabon.

\begin{tabular}{ccccccc}
\hline Variable & Obs. & Mean & Std. Dev. & Min & Max & Std/Mean \\
\hline dsq & 77 & 9.343475 & 5.199593 & 2.905831 & 28.06108 & 0.55659456 \\
ppq & 77 & 58.06227 & 30.61019 & 12.28 & 109.45 & 0.52719589 \\
intq & 77 & 3.046356 & 2.318167 & 1.026447 & 9.012615 & 0.76096392 \\
teerq & 77 & 96.28219 & 7.994597 & 80.71373 & 110.9088 & 0.08303298 \\
\hline
\end{tabular}

Sources: authors on the basis of data (WDI and CNUCED, 2020). 


\subsection{Unit Root Test}

We apply the ADF test to ensure that the series that are used in this study are not included in order I(2). The use of the ARDL model in the cointegration test suggests that the individual series can be integrated into order zero or one. However, for the calculation of the F probability to be valid, it is important to ensure that the $\mathrm{I}(2)$ order series are not included in the model. Thus, to meet this condition, we conduct three-unit root tests: the Dickey-Fuller (ADF). Phillips-Perron (PP) and KPSS tests. The results of the unit root tests are presented in Tables 4-6 and show that all variables are stationary in the first difference. This enables us to estimate the ARDL model for the cointegration of the variables.

\subsection{Model Estimation}

The optimal delay is determined using the information criteria of Schwarz, Akaike and Bayes. The obtained results are presented in Tables 7-9, respectively

Table 4. Time series unit root tests for the Cameroun.

\begin{tabular}{|c|c|c|c|c|c|c|c|}
\hline \multirow[b]{2}{*}{ Variables } & \multirow[b]{2}{*}{$\begin{array}{c}\text { Types } \\
\text { of } \\
\text { tests }\end{array}$} & \multicolumn{3}{|c|}{ Level } & \multicolumn{3}{|c|}{ Difference } \\
\hline & & $\begin{array}{c}\text { With } \\
\text { constant }\end{array}$ & $\begin{array}{c}\text { With } \\
\text { constant } \\
\text { and trend }\end{array}$ & $\begin{array}{l}\text { Without } \\
\text { trend } \\
\text { and } \\
\text { constant }\end{array}$ & $\begin{array}{c}\text { With } \\
\text { constant }\end{array}$ & $\begin{array}{c}\text { With } \\
\text { constant } \\
\text { and } \\
\text { trend }\end{array}$ & $\begin{array}{l}\text { Without } \\
\text { trend and } \\
\text { constant }\end{array}$ \\
\hline \multirow{3}{*}{ DS } & $\mathrm{ADF}$ & $\begin{array}{c}-2.520^{* * *} \\
(0.0070)\end{array}$ & $\begin{array}{c}0.2321 \\
(0.2321)\end{array}$ & $-1.891^{\star}$ & $\begin{array}{c}-3.365^{\star * *} \\
(0.0006)\end{array}$ & $\begin{array}{l}-3.500^{\star *} \\
(0.0394)\end{array}$ & $-3.306^{\star * *}$ \\
\hline & $\mathrm{PP}$ & $\begin{array}{c}-2.350 \\
(0.1563)\end{array}$ & $\begin{array}{c}-1.252 \\
(0.8992)\end{array}$ & $-2.441^{\star \star}$ & $\begin{array}{l}-3.291^{\star *} \\
(0.0153)\end{array}$ & $\begin{array}{l}-3.400^{*} \\
(0.0514)\end{array}$ & $-3.235^{\star * *}$ \\
\hline & KPSS & 1.23 & 0.299 & & $0.303^{* * *}$ & $0.0557^{\star * *}$ & \\
\hline \multirow{3}{*}{$\mathrm{PP}$} & $\mathrm{ADF}$ & $\begin{array}{l}-2.071^{\star} \\
(0.0210)\end{array}$ & $\begin{array}{c}-2.158 \\
(0.5138)\end{array}$ & -0.612 & $\begin{array}{c}-3.219^{* * *} \\
(0.0010)\end{array}$ & $\begin{array}{l}-3.337^{\star} \\
(0.0603)\end{array}$ & $-3.215^{\star * *}$ \\
\hline & $\mathrm{PP}$ & $\begin{array}{c}-1.489 \\
(0.5390)\end{array}$ & $\begin{array}{c}-0.242 \\
(0.9908)\end{array}$ & -0.048 & $\begin{array}{c}-3.164^{\star *} \\
(0.0221)\end{array}$ & $\begin{array}{l}-3.260^{*} \\
(0.0730)\end{array}$ & $-3.159^{\star * *}$ \\
\hline & KPSS & 1.21 & 0.303 & & $0.317^{\star * *}$ & $0.104^{\star * *}$ & \\
\hline \multirow{3}{*}{ Int } & $\mathrm{ADF}$ & $\begin{array}{c}-2.806^{* * *} \\
(0.0032)\end{array}$ & $\begin{array}{c}-2.372 \\
(0.3945)\end{array}$ & $-2.423^{\star \star}$ & $\begin{array}{c}-3.264^{* * *} \\
(0.0008)\end{array}$ & $\begin{array}{c}-3.799^{\star *} \\
(0.0166)\end{array}$ & $-3.151^{\star * *}$ \\
\hline & $\mathrm{PP}$ & $\begin{array}{c}-1.719 \\
(0.4214)\end{array}$ & $\begin{array}{c}-0.175 \\
(0.9920)\end{array}$ & $-1.976^{* *}$ & $\begin{array}{c}-3.163^{\star *} \\
(0.0222\end{array}$ & $\begin{array}{l}-3.539^{\star *} \\
(0.0354)\end{array}$ & $-3.076^{\star * *}$ \\
\hline & KPSS & 1.35 & 0.389 & & $0.348^{* * *}$ & $0.0678^{* * *}$ & \\
\hline \multirow{3}{*}{ Teer } & $\mathrm{ADF}$ & $\begin{array}{l}-1.431^{\star} \\
(0.0784)\end{array}$ & $\begin{array}{c}-4.113^{\star * *} \\
(0.0060)\end{array}$ & 0.650 & $\begin{array}{c}-3.880^{\star * *} \\
(0.0001)\end{array}$ & $\begin{array}{c}-3.837^{\star *} \\
(0.0148)\end{array}$ & $-3.791^{\star * *}$ \\
\hline & $\mathrm{PP}$ & $\begin{array}{c}-0.485 \\
(0.8949)\end{array}$ & $\begin{array}{c}-2.424 \\
(0.3667)\end{array}$ & 1.317 & $\begin{array}{c}-3.717^{\star * *} \\
(0.0039)\end{array}$ & $\begin{array}{l}-3.679^{* *} \\
(0.0238)\end{array}$ & $-3.652^{\star * *}$ \\
\hline & KPSS & 1.79 & $0.116^{\star * *}$ & & $0.0851^{\star * *}$ & $0.0783^{\star * *}$ & \\
\hline
\end{tabular}

Sources: authors on the basis of data (WDI and CNUCED, 2020). 
Table 5. Time series unit root tests for the Congo.

\begin{tabular}{|c|c|c|c|c|c|c|c|}
\hline \multirow[b]{2}{*}{ Variables } & \multirow[b]{2}{*}{$\begin{array}{l}\text { Types of } \\
\text { tests }\end{array}$} & \multicolumn{3}{|c|}{ Level } & \multicolumn{3}{|c|}{ Difference } \\
\hline & & With constant & $\begin{array}{l}\text { With constant } \\
\text { and trend }\end{array}$ & $\begin{array}{l}\text { Without trend } \\
\text { and constant }\end{array}$ & $\begin{array}{c}\text { With } \\
\text { constant }\end{array}$ & $\begin{array}{l}\text { With constant } \\
\text { and trend }\end{array}$ & $\begin{array}{l}\text { Without trend } \\
\text { and constant }\end{array}$ \\
\hline \multirow{3}{*}{ DS } & $\mathrm{ADF}$ & $\begin{array}{l}-4.007^{* * *} \\
(0.0001)\end{array}$ & $\begin{array}{l}-4.592^{* * *} \\
(0.0011)\end{array}$ & -1.328 & $\begin{array}{c}-4.316^{* * *} \\
(0.0000)\end{array}$ & $\begin{array}{c}-4.287^{* * *} \\
(0.0033)\end{array}$ & $-4.316^{\star * *}$ \\
\hline & PP & $\begin{array}{l}-2.023 \\
(0.2767)\end{array}$ & $\begin{array}{l}-2.347 \\
(0.4080)\end{array}$ & \multirow[t]{2}{*}{-0.519} & $\begin{array}{c}-4.062^{\star * *} \\
(0.0011)\end{array}$ & $\begin{array}{c}-4.035^{\star * *} \\
(0.0078)\end{array}$ & \multirow[t]{2}{*}{$-4.066^{\star * *}$} \\
\hline & KPSS & $0.532^{* * *}$ & $0.115^{* * *}$ & & $0.033^{\star * *}$ & $0.0326^{* * *}$ & \\
\hline \multirow{3}{*}{ PP } & $\mathrm{ADF}$ & $\begin{array}{l}-2.071^{* *} \\
(0.0210)\end{array}$ & $\begin{array}{c}-2.158 \\
(0.5138)\end{array}$ & \multirow{3}{*}{-0.048} & $\begin{array}{c}-3.219^{* * *} \\
(0.0010)\end{array}$ & $\begin{array}{l}-3.337^{\star} \\
(0.0603)\end{array}$ & $-3.215^{\star * *}$ \\
\hline & PP & $\begin{array}{c}-1.489 \\
(0.5390)\end{array}$ & $\begin{array}{c}-0.242 \\
(0.9908)\end{array}$ & & $\begin{array}{l}-3.164^{* *} \\
(0.0221)\end{array}$ & $\begin{array}{l}-3.260^{*} \\
(0.0730)\end{array}$ & $-3.159^{* * *}$ \\
\hline & KPSS & 1.21 & 0.303 & & $0.317^{\star \star \star}$ & $0.104^{\star * *}$ & \\
\hline \multirow{3}{*}{ Int } & $\mathrm{ADF}$ & $\begin{array}{l}-3.415^{* * *} \\
(0.0005)\end{array}$ & $\begin{array}{l}-4.789^{* * *} \\
(0.0005)\end{array}$ & \multirow{3}{*}{$-1.618^{\star}$} & $\begin{array}{c}-4.192^{* * *} \\
(0.0000)\end{array}$ & $\begin{array}{c}-4.165^{* * *} \\
(0.0051)\end{array}$ & $-4.210^{\star * *}$ \\
\hline & PP & $\begin{array}{l}-2.128 \\
(0.2333)\end{array}$ & $\begin{array}{c}-2.372 \\
(0.3947)\end{array}$ & & $\begin{array}{l}3.971^{* * *} \\
(0.0016)\end{array}$ & $\begin{array}{l}-3.949^{* *} \\
(0.0104)\end{array}$ & $-3.985^{\star * *}$ \\
\hline & KPSS & 1.14 & $0.115^{\star * *}$ & & $0.0488^{\star * \star}$ & $0.0275^{\star * *}$ & \\
\hline \multirow{3}{*}{ Teer } & $\mathrm{ADF}$ & $\begin{array}{l}-2.304^{* * *} \\
(0.0121)\end{array}$ & $\begin{array}{c}-2.705 \\
(0.2341)\end{array}$ & \multirow[t]{3}{*}{-0.019} & $\begin{array}{l}-3.082 \\
(0.0015)\end{array}$ & $\begin{array}{c}-3.059 \\
(0.1163)\end{array}$ & $-3.098^{\star * *}$ \\
\hline & PP & $\begin{array}{l}-1.010 \\
(0.7495)\end{array}$ & $\begin{array}{c}-1.286 \\
(0.8914)\end{array}$ & & $\begin{array}{l}-3.036^{*} \\
(0.0317)\end{array}$ & $\begin{array}{c}-3.013 \\
(0.1285)\end{array}$ & $-3.051^{\star * *}$ \\
\hline & KPSS & 0.924 & 0.304 & & $0.132^{\star * *}$ & $0.134^{\star * *}$ & \\
\hline
\end{tabular}

Sources: authors on the basis of data (WDI and CNUCED, 2020).

Table 6. Time series unit root tests for the Gabon.

\begin{tabular}{|c|c|c|c|c|c|c|c|}
\hline \multirow[b]{2}{*}{ Variables } & \multirow[b]{2}{*}{$\begin{array}{l}\text { Types of } \\
\text { tests }\end{array}$} & \multicolumn{3}{|c|}{ Level } & \multicolumn{3}{|c|}{ Difference } \\
\hline & & With constant & $\begin{array}{l}\text { With constant } \\
\text { and trend }\end{array}$ & $\begin{array}{l}\text { Without trend } \\
\text { and constant }\end{array}$ & $\begin{array}{c}\text { With } \\
\text { constant }\end{array}$ & $\begin{array}{l}\text { With constant } \\
\text { and trend }\end{array}$ & $\begin{array}{l}\text { Without trend } \\
\text { and constant }\end{array}$ \\
\hline \multirow{3}{*}{ DS } & $\mathrm{ADF}$ & $\begin{array}{l}-4.005^{* * *} \\
(0.0001)\end{array}$ & $\begin{array}{c}-4.371^{* * *} \\
(0.0024)\end{array}$ & $-2.031^{\star *}$ & $\begin{array}{l}-4.253^{* * *} \\
(0.0000)\end{array}$ & $\begin{array}{l}-4.225^{* * *} \\
(0.0041)\end{array}$ & $-4.271^{\star \star \star}$ \\
\hline & PP & $\begin{array}{l}-2.0 .60 \\
(0.2611)\end{array}$ & $\begin{array}{c}-2.267 \\
(0.4523)\end{array}$ & \multirow[t]{2}{*}{-1.203} & $\begin{array}{l}-4.014^{* * *} \\
(0.0013)\end{array}$ & $\begin{array}{l}-3.988^{* * *} \\
(0.0091)\end{array}$ & \multirow[t]{2}{*}{$-4.031^{* * *}$} \\
\hline & KPSS & $0.421^{\star * *}$ & $0.0612^{\star * *}$ & & $0.0354^{\star * \star}$ & $0.0355^{\star * *}$ & \\
\hline \multirow{3}{*}{ PP } & $\mathrm{ADF}$ & $\begin{array}{l}-2.071^{* *} \\
(0.0210)\end{array}$ & $\begin{array}{c}-2.158 \\
(0.5138)\end{array}$ & -0.612 & $\begin{array}{l}-3.219^{* * *} \\
(0.0010)\end{array}$ & $\begin{array}{l}-3.337^{\star} \\
(0.0603)\end{array}$ & $-3.215^{\star * *}$ \\
\hline & PP & $\begin{array}{c}-1.489 \\
(0.5390)\end{array}$ & $\begin{array}{c}-0.242 \\
(0.9908)\end{array}$ & \multirow[t]{2}{*}{-0.048} & $\begin{array}{c}-3.164^{* *} \\
(0.221)\end{array}$ & $\begin{array}{l}-3.260^{*} \\
(0.0730)\end{array}$ & \multirow[t]{2}{*}{$-3.159^{* * *}$} \\
\hline & KPSS & 1.21 & 0.303 & & $0.317^{\star * *}$ & $0.104^{\star * *}$ & \\
\hline \multirow{3}{*}{ Int } & $\mathrm{ADF}$ & $\begin{array}{c}-2.851^{* * *} \\
(0.0028)\end{array}$ & $\begin{array}{l}-3.458^{* *} \\
(0.0441)\end{array}$ & \multirow{3}{*}{$-2.415^{\star *}$} & $\begin{array}{l}-3.900^{* * *} \\
(0.0001)\end{array}$ & $\begin{array}{c}-4.075^{\star * *} \\
(0.0065)\end{array}$ & $-3.750^{* * *}$ \\
\hline & PP & $\begin{array}{c}-1.978 \\
(0.2962)\end{array}$ & $\begin{array}{c}-1.646 \\
(0.7737)\end{array}$ & & $\begin{array}{c}-3.729^{* * *} \\
(37)\end{array}$ & $\begin{array}{l}-3.846^{* *} \\
(0.0144)\end{array}$ & $-3.616^{\star * *}$ \\
\hline & KPSS & 1.39 & 0.261 & & $0.147^{\star * *}$ & $0.0405^{\star * *}$ & \\
\hline \multirow{3}{*}{ Teer } & $\mathrm{ADF}$ & $\begin{array}{l}-2.637^{* * *} \\
(0.0051)\end{array}$ & $\begin{array}{c}-2.719 \\
(0.2284)\end{array}$ & -0.109 & $\begin{array}{l}-3.102^{\star * *} \\
(0.0014)\end{array}$ & $\begin{array}{c}-3.084 \\
(0.1102)\end{array}$ & $-3.138^{\star * *}$ \\
\hline & PP & $\begin{array}{c}-1.119 \\
(0.6740)\end{array}$ & $\begin{array}{c}-1.279 \\
(0.8931)\end{array}$ & \multirow[t]{2}{*}{-0.504} & $\begin{array}{l}-3.040^{* *} \\
(0.0313)\end{array}$ & $\begin{array}{c}-3.020 \\
(0.1266)\end{array}$ & \multirow[t]{2}{*}{$-3.073^{\star * *}$} \\
\hline & KPSS & 0.494 & 0.327 & & $0.136^{\star * *}$ & $0.14^{\star *}$ & \\
\hline
\end{tabular}

Sources: authors on the basis of data (WDI and CNUCED, 2020). 
Table 7. Optimal lag for the Cameroun.

\begin{tabular}{ccccccccc}
\hline lag & LL & LR & df & p & FPE & AIC & HQIC & SBIC \\
\hline 0 & -772.245 & & & & 20241.4 & 9.80589 & 9.80589 & 9.80589 \\
1 & -283.811 & 976.87 & 16 & 0.000 & 0.048458 & -3.1375 & -2.93743 & -2.63548 \\
2 & -170.49 & $226.64^{*}$ & 16 & 0.000 & $0.003382^{*}$ & $-5.80383^{*}$ & $-5.40371^{*}$ & $-4.7998^{*}$ \\
3 & -167.314 & 6.353 & 16 & 0.984 & 0.004856 & -5.4525 & -4.85231 & -3.94645 \\
4 & -160.898 & 12.832 & 16 & 0.685 & 0.006438 & -5.18992 & -4.38967 & -3.18185 \\
\hline
\end{tabular}

Sources: authors on the basis of data (WDI and CNUCED, 2020).

Table 8. Optimal lag for the Congo.

\begin{tabular}{ccccccccc}
\hline lag & LL & LR & df & p & FPE & AIC & HQIC & SBIC \\
\hline 0 & -716.088 & & & & 4345.68 & 8.26734 & 8.26734 & 8.26734 \\
1 & -266.741 & 898.7 & 16 & 0.000 & 0.030357 & -3.60519 & -3.40513 & -3.10317 \\
2 & -148.333 & $236.82^{*}$ & 16 & 0.000 & $0.001843^{*}$ & $-6.41088^{*}$ & $-6.01075^{*}$ & $-5.40684^{*}$ \\
3 & -144.675 & 7.316 & 16 & 0.967 & 0.002612 & -6.07274 & -5.47255 & -4.56669 \\
4 & -139.075 & 11.2 & 16 & 0.797 & 0.003541 & -5.78782 & -4.98756 & -3.77974 \\
\hline
\end{tabular}

Sources: authors on the basis of data (WDI and CNUCED, 2020).

Table 9. Optimal lag for the Gabon.

\begin{tabular}{ccccccccc}
\hline lag & LL & LR & df & p & FPE & AIC & HQIC & SBIC \\
\hline 0 & -910.895 & & & & 903580 & 25.0656 & 25.1156 & 25.1911 \\
1 & -472.453 & 876.88 & 16 & 0.000 & 8.50971 & 13.4919 & 13.7419 & 14.1194 \\
2 & -346.644 & $251.62^{*}$ & 16 & 0.000 & $0.421867^{*}$ & $10.4834^{*}$ & $10.9335^{*}$ & $11.6129^{*}$ \\
3 & -344.27 & 4.745 & 16 & 0.997 & 0.619155 & 10.8568 & 11.507 & 12.4883 \\
4 & -340.099 & 8.3447 & 16 & 0.938 & 0.872939 & 11.1808 & 12.0311 & 13.3144 \\
\hline
\end{tabular}

Sources authors on the basis of data (WDI and CNUCED, 2020).

for Cameroon, Congo, and Gabon.

It appears from Tables 7-9 that the minimum loss of information is reached when the delay is equal to 1 according to the Schwarz criterion and 2 according to the Akaike criterion. Therefore, in this paper, we will use a number of delays of order 2 which corresponds to two quarters.

\subsection{Estimation Results}

The dynamic results of asymmetric cointegration for Cameroon, Congo and Gabon are presented in Table 10. An asymmetric relationship can be identified from the sizes of the coefficients. The decision is based on the joint assumption that the coefficients of the lagged level variables are jointly equal to zero. At the bottom of Table 10, the coefficients $F(27,46)=22.66(0.000)$, $F(27,46)=37.11(0.0000)$, and $F(26,47)=16.85(0.000)$ for Cameroon, Congo and Gabon, respectively, are statistically significant at the $1 \%$ threshold. This implies rejection of the hypothesis, thereby indicating the existence of a long-term 
Table 10. Nonlinear ARDL estimation results fornardllndsq, lnppqlnintqlnteerq, p(2) and $\mathrm{q}(3)$ for Cameroun, Congo, and Gabon.

\begin{tabular}{|c|c|c|c|c|c|c|}
\hline \multirow{2}{*}{-dy } & \multicolumn{2}{|c|}{ Cameroun } & \multicolumn{2}{|c|}{ Congo } & \multicolumn{2}{|c|}{ Gabon } \\
\hline & Coef. & $P>|t|$ & Coef. & $P>|t|$ & Coef. & $P>|t|$ \\
\hline$D S_{(-1)}$ & -0.1921398 & 0.000 & -0.3438125 & 0.000 & -0.5650181 & 0.000 \\
\hline$p p_{(-1)}^{+}$ & -0.0252221 & 0.014 & -0.0056087 & 0.045 & -0.1067386 & 0.001 \\
\hline$p p_{(-1)}^{-}$ & 0.0163911 & 0.011 & 0.0110237 & 0.001 & 0.3652056 & 0.000 \\
\hline$i n t_{(-1)}^{+}$ & 0.2128584 & 0.309 & 0.4930374 & 0.003 & 1.163828 & 0.069 \\
\hline int $t_{t-1}^{-}$ & 0.3916983 & 0.000 & 0.7897673 & 0.000 & 3.925823 & 0.000 \\
\hline teer $r_{t-1}^{+}$ & 0.1323568 & 0.285 & 0.0339169 & 0.265 & 0.8364356 & 0.000 \\
\hline teer $_{t-1}^{-}$. & -0.3356252 & 0.011 & -0.0485039 & 0.018 & -1.164776 & 0.000 \\
\hline _dyL1. & 0.6178889 & 0.000 & 0.6784145 & 0.000 & 0.6265661 & 0.000 \\
\hline$\Delta p p_{(-2)}^{+}$ & -0.0499113 & 0.079 & -0.0133196 & 0.327 & 0.2273109 & 0.019 \\
\hline$\Delta p p_{(-2)}^{-}$ & 0.0329552 & 0.099 & -0.0030349 & 0.745 & 0.3909716 & 0.000 \\
\hline$\Delta i n t_{(-2)}^{+}$ & 1.054262 & 0.039 & 2.533864 & 0.000 & 2.534575 & 0.091 \\
\hline$\Delta i n t_{(-2)}^{-}$ & 1.754981 & 0.000 & 2.00642 & 0.000 & 4.631592 & 0.000 \\
\hline$\Delta$ teer $_{(-2)}^{+}$ & -0.2384761 & 0.362 & -0.0761579 & 0.121 & 0.281584 & 0.223 \\
\hline$\Delta t e e r_{(-2)}^{-}$ & -0.1279147 & 0.669 & 0.02204 & 0.485 & -1.015697 & 0.000 \\
\hline trend & 0.0227047 & 0.659 & 0.0105832 & 0.682 & & \\
\hline _cons & 2.049524 & 0.001 & 0.1866204 & 0.123 & 15.79597 & 0.879 \\
\hline \multicolumn{3}{|c|}{$F(27,46)=22.66(0.000)$} & \multicolumn{2}{|c|}{$F(27,46)=37.11(0.0000)$} & \multicolumn{2}{|c|}{$F(26,47)=16.85(0.000)$} \\
\hline \multicolumn{3}{|c|}{$R^{2}=0.9301$} & \multicolumn{2}{|c|}{$R^{2}=0.9607$} & \multicolumn{2}{|c|}{$R^{2}=0.9378$} \\
\hline \multicolumn{7}{|c|}{ Dynamic asymmetric estimation for the Cameroun } \\
\hline Variable & \multicolumn{3}{|c|}{ Long term Asymmetry } & \multicolumn{3}{|c|}{ Short term Asymmetry } \\
\hline Ppq & \multicolumn{2}{|c|}{24.33} & 0.000 & \multicolumn{2}{|c|}{1.461} & 0.233 \\
\hline intq & \multicolumn{2}{|c|}{0.6806} & 0.414 & \multicolumn{2}{|c|}{0.3443} & 0.560 \\
\hline teerq & \multicolumn{2}{|c|}{4.93} & 0.031 & \multicolumn{2}{|c|}{0.7539} & 0.390 \\
\hline \multicolumn{7}{|c|}{ Dynamic asymmetric estimation for the Congo } \\
\hline Variable & \multicolumn{3}{|c|}{ Long term Asymmetry } & \multicolumn{3}{|c|}{ Short term Asymmetry } \\
\hline Ppq & \multicolumn{2}{|c|}{15.73} & 0.000 & \multicolumn{2}{|c|}{0.03516} & 0.852 \\
\hline intq & \multicolumn{2}{|c|}{3.813} & 0.057 & \multicolumn{2}{|c|}{6.277} & 0.016 \\
\hline teerq & \multicolumn{2}{|c|}{3.069} & 0.087 & \multicolumn{2}{|c|}{5.335} & 0.026 \\
\hline & Dy & amic as & nmetric estim & for the & & \\
\hline Variable & & ng tern & Asymmetry & & rt term Asym & netry \\
\hline Ppq & 45.0 & & 0.000 & & & 0.007 \\
\hline intq & 19.5 & & 0.000 & & & 0.884 \\
\hline teerq & 58.5 & & 0.000 & & & 0.007 \\
\hline
\end{tabular}

Sources: authors on the basis of data (WDI and CNUCED, 2020).

co-movement relationship between the variables and suggesting asymmetry of the relationship in the respective time horizon (long or short term). The presence of long- and short-term asymmetries implies that the positive and negative 
shocks of the underlying regressors must be modeled separately because the shocks are likely differ in terms of impact on the dependent variable.

The results of the tests in Table 10 demonstrate that a $1 \%$ increase in the price of oil leads to a $24.33 \%$ increase in long-term debt service and that a $5 \%$ positive shock on the current account balance leads to a $4.93 \%$ increase in sovereign debt. However, in the long term, the interest rate on sovereign debt is statistically insignificant. In addition, the effects of oil shocks, the interest rate and the current account balance on Cameroon's sovereign debt in the short term are statistically insignificant. Thus, in Cameroon, the debt depends more on positive shocks than on negative shocks; therefore, short-term asymmetric shocks are influenced by the long-term behavior. The improvement in the current account balance can be justified by the rise in oil prices. Under these conditions, Cameroon, similar to most developing countries, pursues a pro-cyclical fiscal policy.

In Congo, the positive responses of the debt to the oil price, interest rate and real effective exchange rate shock $\left(p p^{+}=15.73\right.$, int $t^{+}=3.813$ and $\left.t e e r^{+}=3.069\right)$ are significant at the $1 \%$ and $5 \%$ thresholds. For the response to a negative shock, only the interest rate (int $=6.277)$ and the real effective exchange rate (teer $\left.\bar{r}^{-}=5.335\right)$ are statistically significant at the 5\% threshold. Regarding the positive shock, a $1 \%$ increase in the price of oil leads to an increase in sovereign debt of $15.73 \%$, while a rise in the interest rate and anincrease in the current account balance of $5 \%$ lead to increases in debt of $3.813 \%$ and $3.069 \%$, respectively.

Conversely, in the short term, a fall in the interest rate and deterioration in the real effective exchange rate of $5 \%$ would lead to increases in debt of $6.277 \%$ and $5.335 \%$, respectively. The lower interest rate is favorable for Congo's access to credit, thereby offsetting the negative effects of the deterioration in the current account balance. Theoretically, this places the Congo in a scenario of high demand for foreign capital, while simultaneously and implicitly, the interest rate is rising. As a result, there is an increase in debt, which is denominated in foreign currency. The Congo has a pro-cyclical fiscal policy.

In the case of Gabon, the positive responses of the debt to the price of oil, the interest rate and the real effective exchange rate $\left(p p^{+}=45.03\right.$, int $t^{+}=19.52$ and teer $\left.^{+}=58.58\right)$ are significant at the $1 \%$ threshold. The responses to a negative shock $\left(p p^{-}=8.151\right.$ and teer $\left.=8.25\right)$ are also significant at the $1 \%$ threshold. With respect to a positive shock, improvements in oil prices, interest rates, and the real effective exchange rate of $1 \%$ lead to increases in sovereign debt of $45.03 \%, 19.52 \%$, and $58.58 \%$, respectively. In contrast, in the short term, $1 \%$ decreases in oil prices and in the current account balance lead to deteriorations in debt service of $8.151 \%$ and $8.25 \%$, respectively.

These results demonstrate the asymmetrical short- and long-term relationships among the oil price, the interest rate, the current account balance and the sovereign debt. Thus, in the long run, Gabon's debt increases as the rise in oil prices contributes simultaneously to the increase of the current account balance. In contrast, following a negative short-term shock, there is a decrease in sovereign debt service. 
In addition, to evaluate the relevance of the estimated dynamic model, we examined several diagnostic statistics of the model. The Jarque-Bera test was used to evaluate the normality (chi2), the Ramsey Reset LM test (F) was used to evaluate the functional form, the LM series correlation test (chi2) was used to evaluate the autocorrelation, and the Breusch-Pagan heteroskedasticity test (chi2) was also applied. The results are presented at the bottom of Table 11. For Cameroon and Congo, the model passed all diagnostic tests, thereby suggesting error normality, absence of autocorrelation and parameter stability. For Gabon, the model did not pass all tests. In addition, the model presents $R_{\text {Cam }}^{2}=93 \%$, $R_{\text {Cog }}^{2}=96 \%$, and $R_{G a b}^{2}=93 \%$ for Cameroon, Congo and Gabon, respectively, which are well above 50\%; thus, the modelfit is regarded as adequate. Consequently, the dynamics of oil price shocks are sufficiently specified.

Graphs 4-6 show the dynamic effects of positive and negative changes in oil, interest rates, and current account balance shocks on the sovereign debt of $\mathrm{Ca}$ meroon, Congo, and Gabon.

According to Graph 4, which presents Cumulative effects of oil, interest rate, and current account balance shocks on the sovereign debt of Cameroun, the sovereign debt reacts to positive and negative oil price shocks but with larger negative effects that extend into the long term. It is also sensitive to positive real

Table 11. Asymmetry test and model diagnostics.

\begin{tabular}{|c|c|c|}
\hline \multicolumn{3}{|c|}{ Asymmetry test and model diagnostics for Cameroun } \\
\hline Test & Stat. & p-value \\
\hline Portmanteau test up to lag 35 (chi2) & 23.58 & 0.9289 \\
\hline Breusch/Pagan heteroskedasticity test (chi2) & 2.665 & 0.1026 \\
\hline Ramsey RESET test (F) & 0.8526 & 0.4729 \\
\hline Jarque-Bera test on normality (chi2) & 2.701 & 0.2591 \\
\hline \multicolumn{3}{|c|}{ Asymmetry test and model diagnostics for Congo } \\
\hline Test & Stat. & p-value \\
\hline Portmanteau test up to lag 35 (chi2) & 43.55 & 0.1523 \\
\hline Breusch/Pagan heteroskedasticity test (chi2) & 2.739 & 0.0979 \\
\hline Ramsey RESET test (F) & 1.461 & 0.2393 \\
\hline Jarque-Bera test on normality (chi2) & 5.656 & 0.0591 \\
\hline \multicolumn{3}{|c|}{ Asymmetry test and model diagnostics for Gabon } \\
\hline Test & Stat. & p-value \\
\hline Portmanteau test up to lag 35 (chi2) & 48 & 0.0562 \\
\hline Breusch/Pagan heteroskedasticity test (chi2) & 0.2486 & 0.6181 \\
\hline Ramsey RESET test (F) & 0.4222 & 0.7383 \\
\hline Jarque-Bera test on normality (chi2) & 2.518 & 0.2839 \\
\hline
\end{tabular}

Sources: authors on the basis of data (WDI and CNUCED, 2020). 


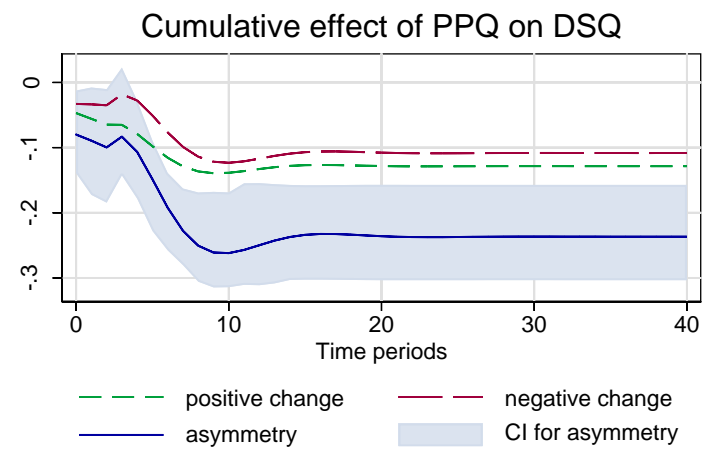

Note: $95 \%$ bootstrap $\mathrm{Cl}$ is based on 100 replications

\section{Cumulative effect of TEERQ on DSQ}

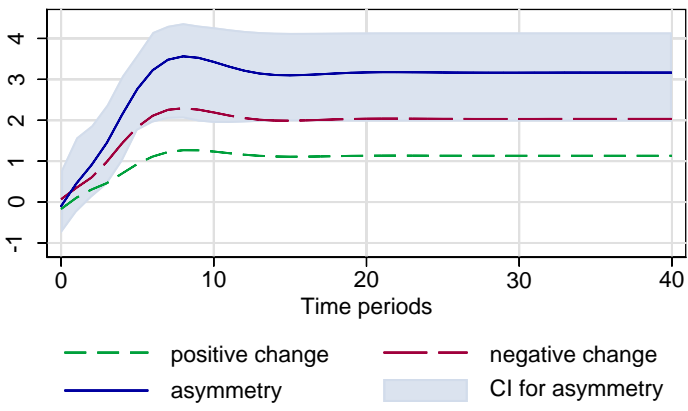

Note: $95 \%$ bootstrap $\mathrm{Cl}$ is based on 100 replications

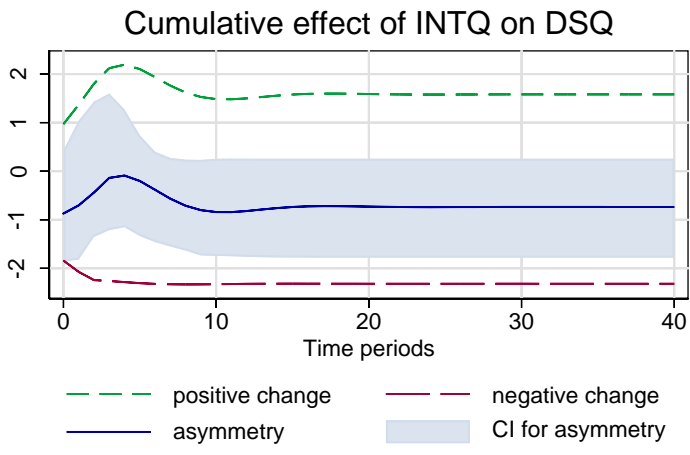

Note: $95 \%$ bootstrap $\mathrm{Cl}$ is based on 100 replications

Graph 4. Cumulative effects of oil, interest rate, and current account balance shocks on the sovereign debt of Cameroun. Sources: authors on the basis of data (WDI and CNUCED, 2020).

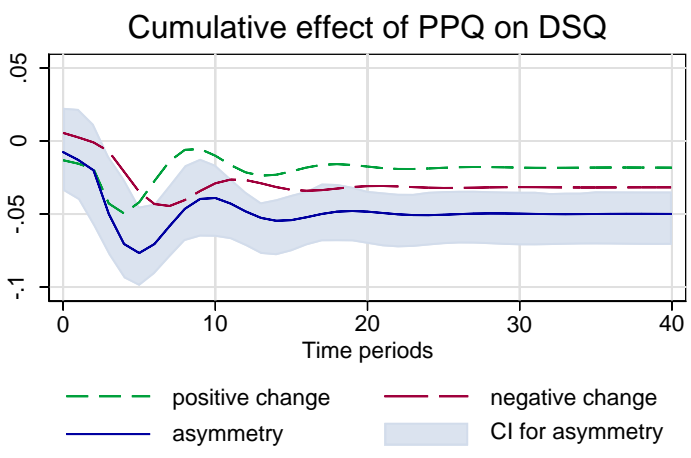

Note: $95 \%$ bootstrap $\mathrm{Cl}$ is based on 100 replications

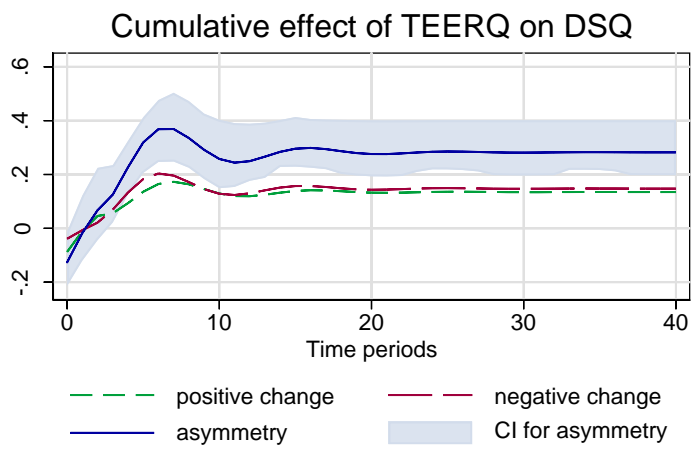

Note: $95 \%$ bootstrap $\mathrm{Cl}$ is based on 100 replications

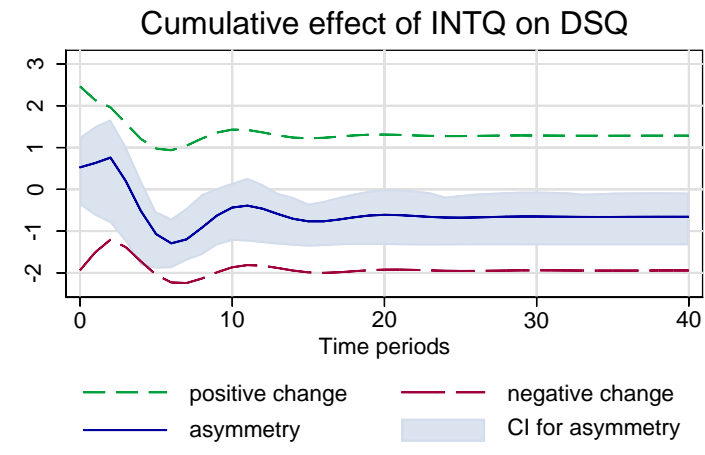

Note: $95 \%$ bootstrap $\mathrm{Cl}$ is based on 100 replications

Graph 5. Cumulative effects of oil, interest rate, and current account balance shocks on the sovereign debt of Cong. Sources: authors on the basis of data (WDI and CNUCED, 2020). 


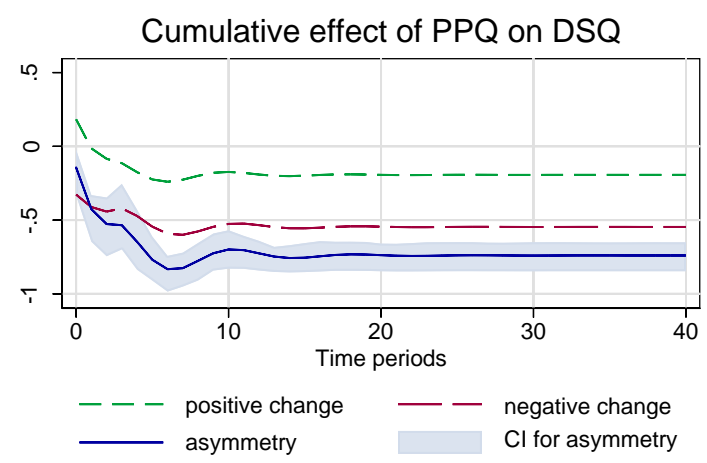

Note: $95 \%$ bootstrap $\mathrm{Cl}$ is based on 100 replications

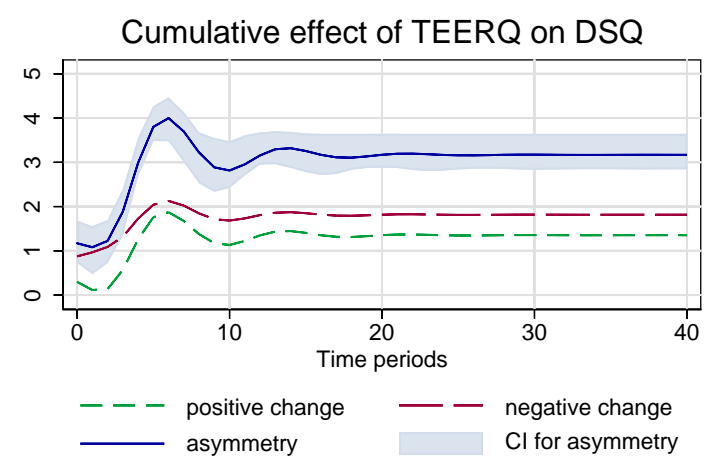

Note: $95 \%$ bootstrap $\mathrm{Cl}$ is based on 100 replications

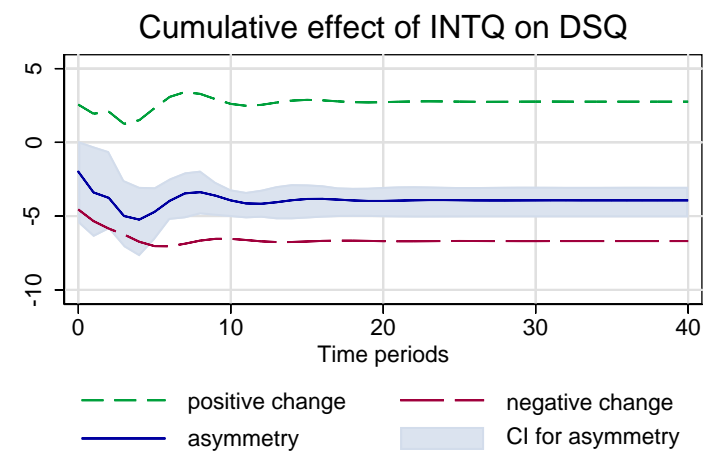

Note: $95 \%$ bootstrap $\mathrm{Cl}$ is based on 100 replications

Graph 6. Cumulative effects of oil, interest rate, and current account balance shocks on the sovereign debt of Gabon. Sources: authors on the basis of data (WDI and CNUCED, 2020).

effective exchange rate effects that persist over time. With respect to the cumulative effects of the interest rate, the results are not significant. From this analysis, we conclude that sovereign debt is pro-cyclical vis-à-vis oil in Cameroon and that in the long term, the effect of a negative shock is more significant. The reaction of the debt to the interest rate reveals the weaknesses of the fixed exchange rate regime in the short term, and the positive effects of the real effective exchange rate show that the improvement in the price of oil leads to an increase in sovereign debt.

For the Congo, the debt reacts to negative and positive oil price shocks as early as period zero to period ten but is more influenced by negative shocks in the short and long terms. This shows that Congo's sovereign debt is more sensitive to negative oil price shocks. Similarly, it is more influenced by negative interest rate effects than by positive effects Graph 5 . However, the sovereign debt is more sensitive to the positive effects of the real effective exchange rate. The improvement in the current account balance leads to the government's financial commitment to the rest of the world.

With respect to Gabon, Graph 6 shows that the debt is more sensitive to the negative effects of oil prices, in both the short and long terms. Therefore, Gabon must pursue economic policies that limit its dependence on the oil sector. However, the sovereign debt is more affected by the negative effects of interest rates in the short and long terms and is more sensitive to the cu- 
mulative positive effects of the current account balance, as in Cameroon and Congo.

In summary, in all three cases, the sovereign debt is more sensitive to the negative effects of oil prices and interest rates; in addition, it is sensitive to the positive effects of the current account balance. Thus, these countries are vulnerable to the resilience of negative oil price shocks, and they must pursue economic policies that can absorb these shocks.

\section{Conclusion and Policy Implications}

The objective of this paper was to analyze the effects of asymmetric oil price shocks to the interest rates and current account balances on the sovereign debts of Cameroon, Congo and Gabon over a period from 1998 to 2018. To realize this objective, a combination of literature research and statistical and econometric analyses was used. The results that were obtained via the NARDL method demonstrated long- and short-term asymmetric relationships among these four variables with long-term asymmetries in the three countries. This highlights the sensitivity of these economies to oil price shocks.

Indeed, there is a positive correlation between short- and long-term oil shocks. Thus, a rise in oil prices leads to an increase in sovereign debt, whereas a fall in oil prices leads to deterioration in the debt-service-to-exports ratio. Thus, being in a monetary zone with a fixed exchange rate, a monetary policy that tends to devalue the currency to increase exports can be counterproductive. Consequently, these countries must opt for diversification of their economies. Two lessons can be drawn from these policies:

- Devaluation is counterproductive.

In these three countries, where exports are almost concentrated, devaluation tends to exacerbate the deterioration of the current account balance because the adjustment between old export and import contracts with the old exchange rate and new contracts with the new exchange rate does not occur automatically. As a result, a decline in reserves contributes to a decline in aggregate savings, which are needed to finance public investment. Thus, a deficit in the balance of payments systematically leads to a deficit in the primary balance. To remedy this situation, diversification is the best policy.

- Diversification is a necessity for mitigating shocks (Ayessa, 2020).

Diversification helps cushion an economy against negative shocks insofar as it enables the resolution of the Dutch disease (from which oil-producing countries suffer) by respecting the classic pattern of structural transformation of the economy.

Finally, in this paper, taking institutional variables into account would better explain the procyclicality of the fiscal policy in force in these countries.

\section{Conflicts of Interest}

The authors declare no conflicts of interest regarding the publication of this paper. 


\section{References}

Abdel-Latif, H., Osman, R. A., \& Ahmed, H. (2018). Asymmetric Impacts of Oil Price Shocks on Government Expenditures: Evidence from Saudi Arabia. Cogent Economics \& Finance, 6, Article ID: 1512835. https://doi.org/10.1080/23322039.2018.1512835

Adedeji, A. N., Ahmed, F. F., \& Muhammed, M. (2018). Empirical Evidence of Oil Price Shocks and Oil Economy Asymmetric Nexus: The Cases of Angola and Nigeria. Advances in Social Sciences Research Journal, 5, 17-32.

https://doi.org/10.14738/assrj.56.4649

Aguiar, M., \& Amador, M. (2016). Sovereign Debt. In E. Helpman, K. S. Rogoff, \& G. Gopinath (Eds.), Chapter 11 Handbook of International Economics (Vol. 4, pp. 647-687). Amsterdam: Elsevier. https://doi.org/10.1016/B978-0-444-54314-1.00011-2

Aguiar, M., \& Gopinath, G. (2004). Defaultable Debt, Interest Rates and the Current Account. Journal of International Economics, 69, 64-83.

https://doi.org/10.1016/j.jinteco.2005.05.005

Allegret, J.-P., Couharde, C., Mignon, V., \& Razafindrabe, T. (2015). Oil Currencies in the Face of Oil Shocks: What Can Be Learned from Time-Varying Specifications? CEPII Working Paper No. 18. https://doi.org/10.1080/00036846.2016.1226490

Arellano, C. (2008). Default Risk and Income Fluctuations in Emerging Economies. American Economic Review, 98, 690-712. https://doi.org/10.1257/aer.98.3.690

Ayessa, E. B. (2020). Diversification économique dans les pays membre de la CEMAC: Déterminants et Effets d'atténuation des chocs. Thesis, Université Marien NGOUABI.

Bernanke, B. S., Gertler, M., \& Watson, M. (1997). Systematic Monetary Policy and the Effects of Oil Price Shocks. Brookings Papers on Economic Activity, 1, 91-142. https://doi.org/10.2307/2534702

Blanchard, O. J., \& Galí, J. (2008). The Macroeconomic Effects of Oil Price Shocks: Why Are the 2000s So Different from the 1970s? In J. Galí, \& M. Gertler (Eds.), International Dimensions of Monetary Policy (pp. 1-77). Chicago, IL: University of Chicago Press. https://doi.org/10.3386/w13368

Bruno, M., \& Sachs, J. D. (1985). Economics of Worldwide Stagflation. Cambridge, MA: Harvard University Press.

Buetzer, S., Habib, M. M., \& Stracca, L. (2012). Global Exchange Rate Configurations. Do Oil Shocks Matter? European Central Bank, Working Paper Series.

Bulow, J., \& Rogoff, K. S. (1989). A Constant Recontracting Model of Sovereign Debt. Journal of Political Economy, 97, 155-178. https://doi.org/10.1086/261596

Bulow, J., \& Rogoff, K. S. (1988). Sovereign Debt: Is to Forgive to Forget. American Economic Review, 79, 43-50. https://doi.org/10.3386/w2623

Denton, F. (1971). Adjustment of Monthly or Quarterly Series to Annual Totals: An Approach Based on Quadratic Minimization. Journal of the American Statistical Association, 66, 99-102. https://doi.org/10.1080/01621459.1971.10482227

Di Fonzo, T., \& Marini, M. (2012). On the Extrapolation with the Denton Proportional Benchmarking Method. IMF Working Papers, 2012, 21. https://doi.org/10.5089/9781475505177.001

Eaton, J., \& Gersowitz, M. (1981). Debt with Potential Repudiation: Theoretical and Empirical Analysis. Review of Economic Studies, 48, 289-309. https://doi.org/10.2307/2296886

Edelstein, P., \& Kilian, L. (2007). Retail Energy Prices and Consumer Expenditures. 
Working Paper, Ann Arbor, MI: University of Michigan.

Flood, R. P., \& Olivier, J. (2005). An Interest Rate Defense of a Fixed Exchange Rate? Journal of International Economics, 66, 471-484. https://doi.org/10.1016/j.jinteco.2004.09.001

Frankel, J., \& Rose, A. (1996). Currency Crises in Emerging Markets: An Empirical Treatment. Journal of International Economics, 41, 351-366. https://doi.org/10.1016/S0022-1996(96)01441-9

Goldfajn, I., \& Valdés, R. (1996). The Aftermath of Real Appreciations. NBER Working Paper No. 5650. https://doi.org/10.3386/w5650

Hamilton, J. D. (1996). This Is What Happened to the Oil Price-Macroeconomy Relationship. Journal of Monetary Economics, 38, 215-220. https://doi.org/10.1016/S0304-3932(96)01282-2

Herrera, A. M., \& Pesavento, E. (2007). Oil Price Shocks, Systematic Monetary Policy and the "Great Moderation". Macroeconomic Dynamics, 13, 107-137. https://doi.org/10.1017/S1365100508070454

Hooker, M. (1996). What Happened to the Oil Price-Macroeconomy Relationship? Journal of Monetary Economics, 38, 195-213. https://doi.org/10.1016/S0304-3932(96)01281-0

Kaminsky, G. L. (2003). Varieties of Currencies Crises. NBER 10193. https://doi.org/10.3386/w10193

Kilian, L. (2008). The Economic Effects of Energy Price Shocks. Journal of Economic Literature, 46, 871-909. https://doi.org/10.1257/jel.46.4.871

Kilian, L. (2009). Not All Oil Price Shocks Are Alike: Disentangling Demand and Supply Shocks in the Crude Oil Market. American Economic Review, 99, 1053-1069. https://doi.org/10.1257/aer.99.3.1053

Lahiri, A., \& Végh, C. (2003). Delaying the Inevitable: Optimal Interest Rate Policy and BOP Crises. Journal of Political Economy, 111, 404-424. https://doi.org/10.1086/367682

Mankiw, N. G., Romer, D., \& Weil, D. (1992). A Contribution to the Empirics of Economic Growth. The Quarterly Journal of Economics, 107, 407-437.

Pesaran, M. H., \& Shin, Y. (1998). An Autoregressive Distributed-Lag Modelling Approach to Cointegration Analysis. Econometric Society Monographs, 31, 371-413. https://doi.org/10.1017/CBO9781139052221.011

Pesaran, M. H., Shin, Y., \& Smith, R. J. (2001). Bounds Testing Approaches to the Analysis of Level Relationships. Journal of Applied Econometrics, 16, 289-326. https://doi.org/10.1002/jae.616

Reinhart, C. M., \& Rogoff, K. S. (2009). The Aftermath of Financial Crises. Working Paper 14656. http://www.nber.org/papers/w14656 https://doi.org/10.3386/w14656

Reinhart, C. M., Rogoff, K. S., \& Savastano, M. A. (2003). Debt Intolerance. Brookings Papers on Economic Activity, 1, 1-74. https://doi.org/10.3386/w9908

Schorderet, Y. (2003). Asymmetric Cointegration. Working Paper, Geneva: Econometrics Department, University of Geneva. https://core.ac.uk/download/pdf/7134653.pdf

Shin, Y., Yu, B., \& Greenwood-Nimmo, M. (2014). Modelling Asymmetric Cointegration and Dynamic Multipliers in a Nonlinear ARDL Framework. In Festschrift in Honor of Peter Schmidt (pp. 281-314). New York: Springer. https://doi.org/10.1007/978-1-4899-8008-3_9 
Tomz, M., \& Wright (2007). Do Countries Default in Bad Times? Journal of the European Economics Association, 5, 352-360. https://doi.org/10.1162/jeea.2007.5.2-3.352

Tomz, M., \& Wright, M. L. J. (2013). Empirical Research on Sovereign Debt and Default. nber/w18855. https://doi.org/10.3386/w18855 